\title{
New and little-known Psocoptera from the Reserva Ducke, Amazonas
}

\author{
T. R, New $\left({ }^{*}\right)$
}

\section{Abstract}

New Brazilian species of Musapsocus (1), Thyrsopsocus (1), Psococerastis (1), Metylophorus (1), Psocidus (1), Myopsocus (1), Phlotodes (1), and Lophopterygella (2) are described and figured, and augmented des. criptions given of Cervopsocus medialis New and Psocidus quadrisignatus (Banks). Musapsocus and Lophopterygella are here recorded from Brazil for the first time.

\section{INTRODUCTION}

This paper contains notes on, and descriptions of. several noteworthy Psocoptera collected by Drs. J. Arias and N. D. Penny during their survey of the Reserva Ducke (3\%08'S, 60:02'W, $26 \mathrm{~km}$ from Manaus along Highway Am-010, Amazonas, Brazil), an area of primary rain forest. It deals with an Electrentomoid, Myopsocidae, and some parts of Psocidae. The single Electrentomoid collected represents a genus new to Brazil (Musapsocus Mockford), and the Myopsocidae comprise four new species, two of which represent a genus not previously recorded from mainland South America. The Psocidae are mainly representatives of groups which have recently been more comprehensively reappraised, but two anomalous taxa are also included. Other Psocidae will be treated. together with other taxa in the collection. elsewhere.

For conciseness, only the trapping method and date are given for the following species: all are from the above locality, and were coilected by J. Arias or N. D. Penny. Types of new species will be deposited in the collections of INPA (Manaus), and abbreviations are as in an earlier paper (New, in press. All measurements are given in $\mathrm{mm}$.

\section{MUSAPSOCIDAE}

\author{
Musapsocus mockfordi sp. n.
} (Figs. 1-6)

FEIMALE, Unknown.

MALE. Coloration. Pale brown. Eyes black. Ocelli small, with black crescents along inner borders. Postclypeus slightly greyed; head otherwise unmarked. Dorsum of thorax slightly darkened. Wings unmarked, venation brown Legs and abdomen pale.

Morphology. Forewing venation (Fig. 1): areola postica long and shallow; vein A2 ending free in membrane. Hindwing venation as in Fig. 2. Lacinial apex (Fig. 3) slender, elongate outer tine with small inner tine well behind apex; third tine tapered. Hypandrium simple, transverse. Phallosome (Fig. 4) slender; outer branches of parameres very slender and tapered; inner branches broader. sinuous. Last tergite (Fig. 5) with opposed 'C's of small denticles. Epiproct (Fig. 6) shallow, broad, with setae at and near apex. Paraproct elongate, with field of 14 trichobothria.

Dimensions. B. 1.90, FW 1.76, HW 1.44, $f_{1} 0.225, f_{2} 0.225, f_{1} / f_{2} 1.00, F 0.435, T 0.780$, $t_{1} 0.285, t_{2} 0.135, t_{1} / t_{2} 2.111$.

Holotype, \&, Malaise trap, 6.ix.1978.

\section{COMMENTS}

The few known species of Musapsocus Mockford (1967) are known from Mexico (2). Costa Rica (1), Venezuela (1), and Trinidad (1). The present species is most similar to the two Mexican taxa, huastecanus Mockford and tabascensis Mockford. In mockfordi and huastecanus the phallosome is narrow but the

$\left({ }^{\circ}\right)$ - Department of Zoology, La Trobe University, Bundoora, Victoria, 3083, Australia. 


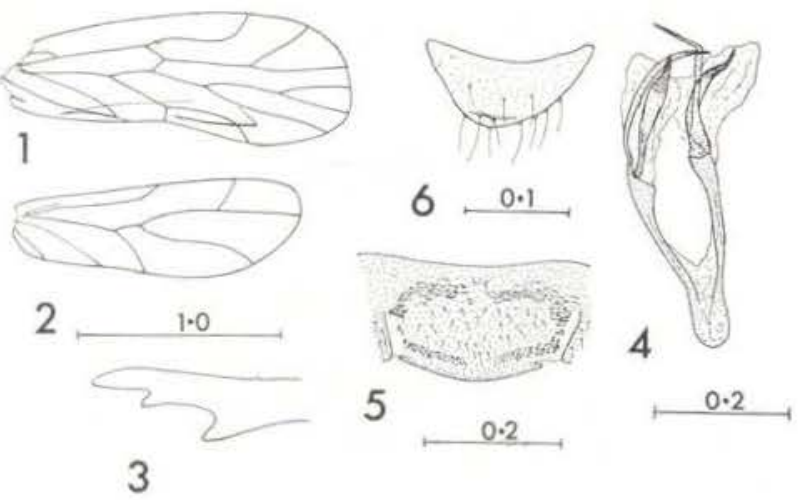

Figs. 1-6. Musapsocus mockfordi sp. n.: Fig. $1-$ Forewing; Fig. 2 - Hindwing; Fig. 3 - Lacinial apex; Fig. 4 - Phallosome; Fig. 5 - Male clunium; Fig. 6 Male epiproct. (Scales in $\mathrm{mm}$ ).

two species differ markedly in epiproct and clunial features. The lacinia of mockfordi resemblles that of tabascensis in that the outer tine is very slender, and both species have the outer paramere branches very long. The phallosome of mockfordi is much narrower. and the clunial ornamentation also differs considerably.

\section{PSOCIDAF}

\section{Thyrsopsocus (Thyrsopsocus) brasiliensis}

sp. n.

(Figs. 7-13)

FEMale, Male, Coloration. Pale brown. Eyes black. Ocellar tubercle slightly darkened. Central region of face with dark brown stripe; genae darkened; postclypeus with traces of striae. Maxillary palpi pale. Antennae pale basally, $f_{1}$ darkened black after basal third. Thorax black dorsally, pale laterally. Legs pale. Forewing (Figs, 7,11) strongly marked with orange-brown; basal markings dark greyish brown. Hindwing darkened basally. Abdomen pale.

Morphology, Female. Forewing as in Fig. 11. Subgenital plate (Fig. 12) with rounded apical lobe; this sclerotised along central axis to link with anterior sclerotised crescent and transverse bar; lateral areas lightly sclerotised. Gonapophyses (Fig. 13): dorsal valve tapered and spiculate near apex; external valve very broad. Epiproct rounded. Paraproct with field of about 26 trichobothria.

Male. Forewing as in Fig. 7. Hypandrium (Fig. 8) symmetrical, with broad rugose dorsolateral lobes; a broad transverse posterior crest; strongly convex. Phallosome (Fig. 9) with long tapered posterior spike; frame broadened anteriorly. Clunium (Fig. 10) expanded, broad, slightly emarginate medially. Epiproct (Fig. 10) tapered. Paraproct (Fig. 10) with strong basal rod, slender curved apica! spine and a field of about 24 trichobothria.

Dimensions. Female, B 7.40, FW 6.27 HW' $4.02, f_{1} 2.68$, hind leg missing.

Male, B 5.20, FW 4.60-4.79, HW 2.92-3.16. $f_{1} 2.060, f_{2} 1.916, f_{1} / 2$ 1.075, F 1.305-1.320, T 2.205, $t_{1} \quad 0.735-0.780, t_{2} 0.210, t_{1} / t_{2} 3.500$ 3.714, ct 33-34.3-4.

Holotype, ô, Malaise trap, 18.x.1978.

Paratypes, 3 o $\delta$, Malaise trap, 29.xi.1977. 24.i.1978, 6.ix.1978; 1 ㅇ. Malaise trap 6.ix.1978.

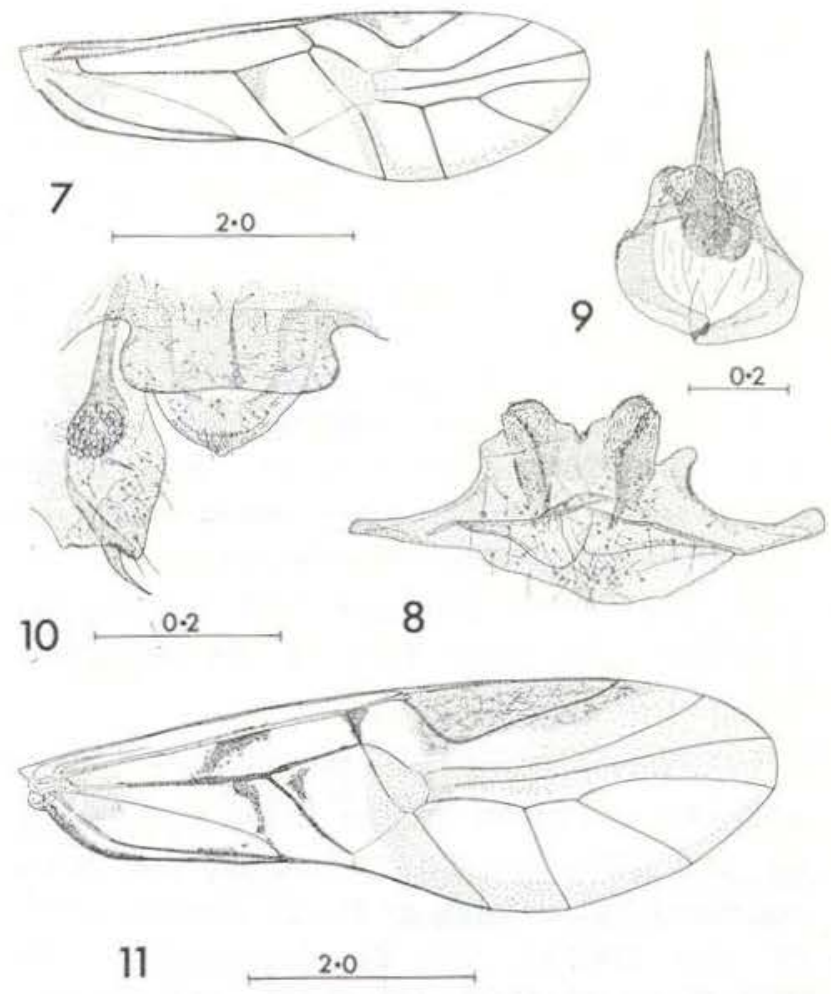

Figs. 7-11. Thyrsopsocus (Thyrsopsocus) brasiliensis sp. n.: Fig. 7 - Male forewing; Fig. 8 - Hypandrium; Fig. 9 - Phallosome; Fig. 10 - Male clunium, epiproct and paraproct; Fig. 11 - Female forewing: [Scales in $\mathrm{mm}$ ). 


\section{COMMENTS}

This species if very similar to $T$. (T.) bellus (McLachlan) as diagnosed by New (1978a), in which the forewing markings are somewhat variable. It is possible that the two sexes represent different species, but the close similarity in body coloration, together with the absence of other male Thyrsopsocus, strongly suggests that only one species is represented. Males differ from bellus considerably in the form of the hypandrium and phalloscme: in particular, bellus bears rows of larger spines on the hypandrium and has the posterior phallosome blunt rather than forming a distinct spike. Females are less distinctive, but the external gonapophysis valve of brasiliensis is broader than that of bellus.

\section{Psococerastis amazonica $\mathrm{sp} . \mathrm{n}$.} (Figs. 14-16)

female. Coloration. Pale brown. Eyes dark grey. Ocelli with black crescents along inner margins. Vertex with groups of small brown

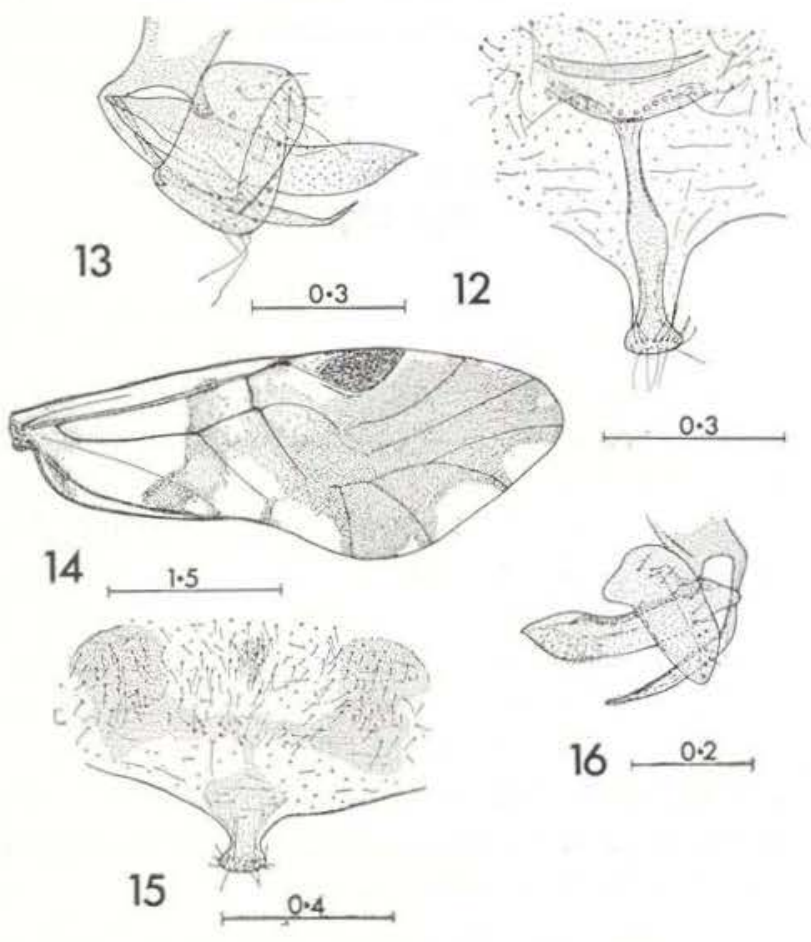

Figs. 12-16. Figs. 12-13 - Thyrsopsocus (T.) brasiliensis sp. n.: Fig. 12 - Subgenital plate; Fig. 13 - Gonapophyses. Figs. 14-16 - Psococerastis amazonica sp. n.: Fig. 14 - Forewing; Fig. 15 - Subgenital plate; Fig. 16 - Gonapophyses. (Scales in $\mathrm{mm}$ ). spots across posterior, along midline and narrowly dorsal to eyes. Postclypeus with traces of 4-6 narrow striae each side of midline; anteclypeus pale; labrum darkened. Maxillary palpi dark brown. Antennae blackened beyond basal half of $f_{1}$. Thorax darkened dorsally, pale laterally. Legs mainly pale: $F_{3}$ darkened near apex; apices of all tibiae dark whole of tarsi dark brown. Forewing marked with dark greyish brown as in Fig. 14. Hindwing hyaline. Abdomen mainly pale, with traces of darker dorsal markings.

Morphology. Forewing venation as in Fig. 14. Subgenital plate (Fig. 15) witi short expanded median lobe: a small median sclerotised patch anterior to main sclerotised area. Gonapophyses (Fig. 16): ventral and dorsal valves spiculate near apex; external valve transverse, with small lobe. Epiproct tapered, rounded at apex. Paraproct with field of about 32 trichobothria.

Dimensions. B 4.70, FW 4.55, HW 3.07. $f_{1} 1.230, f_{2} 1.500, f_{1} / f_{2} 0.820, F 0.870$ T 1.770 , $t_{1} 0.450, t_{2} 0.210, t_{1} / t_{2} 2.143$, ct 20.6 .

Male. Unknown.

Holotype, ㅇ, Malaise trap, 5.xii.1977.

\section{COMMENTS}

This species is clearly related to those noted by New (1978b) as belonging to the 'Psococerastis taprobanes complex.' Most of the described South American species in this group have the forewing less heavily marked, and only in sticticus (Banks, 1920) does the intensity of pigmentation approach the condition in amazonica. The two apparently differ in (1) sticticus has the basal bar linked to the distal pigmentation by pigment along $\mathrm{M}$ before $R_{\mathrm{S}}$, whereas amazonica is linked through the centre of the discoidal cell, and (2) amazonica has most of cell $R_{1}$ darkened, whereas, in sticticus the cell is not darkened beyond the widest part of the pterostigma. Genitalia of sticticus have not been described. $P$. amazonica has female genitalia closely resembling those of $P$. callanganus (Enderlein 1900) known from Peru and Brazil and represented in the present collection by several females: in all, the 
forewing is much more lightly marked (see Figs. 31-33 of New 1978b), but the anterior sclerotised patch on the subgenital plate indicates that the two species may be closely related.

\section{Cervopsocus medialis New}

Cervopsocus medialis New 1978c: 15, Figs. 9.14 (ô, Brazil)

(Figs. 17-19)

FEmale, Coloration. As in original description except: lateral regions of postclypeus un marked, antennae with apex of scape and of pedicel black, anterior half of abdomen irregularly darkened dorsaliy.

Morphology. Forewing as in original description. Subgenital plate (Fig. 17) with short bluntly-rounded median process; base of process with arcuate inner thickenings; an

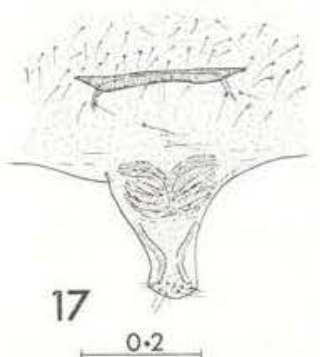

19
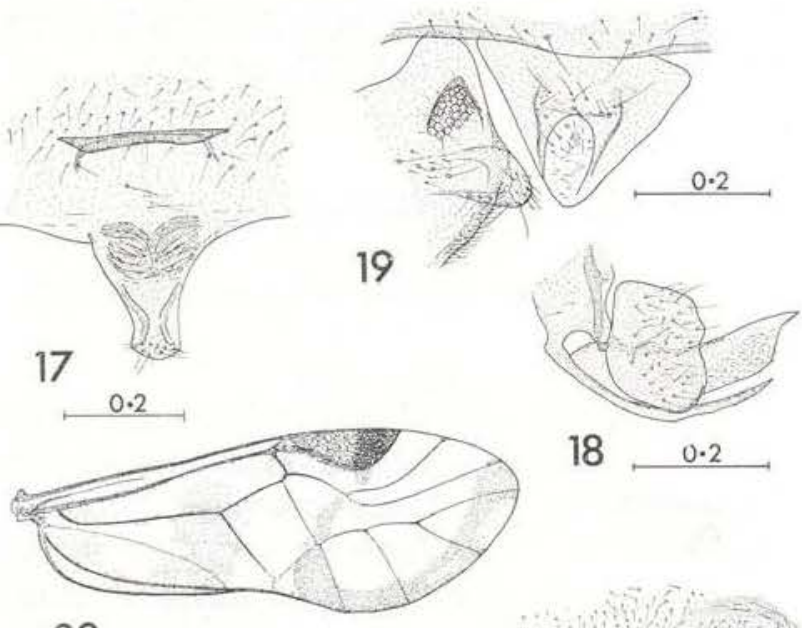
$2 \cdot 0$

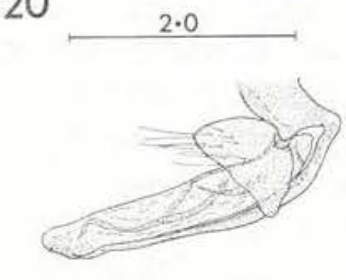

22. 0.5
18 0.2
Figs. 17-22. Figs. 17-19 - Cervopsocus medialis New: Fig. 17 - Subgenital plate; Fig. 18 - Gonapophyses; Fig. 19 - Female epiproct and paraproct. Figs 20-22 Metylophorus fasciatus sp. n.: Fig. 20 - Forewing; Fig, 21 - Subgenital plate; Fig. 22 - Gonapophyses (Sca. les in $\mathrm{mm}$ ) anterior sclerotised bar. Gonapophyses (Fig 18): ventral valve slender and spiculate near apex; dorsal valve spiculate, with siignt apical projection; external valve very broad, without apical lobe. Epiproct (Fig. 19) deep, tapered to narrow rounded apex. Paraproct (Fig. 19) with field of about 24 trichobothria.

Dimensions. B 4.60, FW 4.31, HW 2.97, $F 0.945, T 1.815, t_{1} 0.480, t_{2} 0.165, t_{1} / t_{2} 2.909$, ct 25.3 .

Material examined, 이 light trap 17.i.1978.

\section{COMMENTS}

Cervopsocus was described from males only (New 1978c), and this specimen is the first known female. As in many other Psocidae, the female is somewhat larger than the corresponding male, but is clearly referable to the same species. The following are additional to the generic diagnosis: subgenital plate with short median lobe and anterior sclerotised bar; gonapophyses with dorsal valve bearing short apical projection and external valve lacking apical lobe. The latter feature confirms the generic placement in the Metylophorini.

\section{Metylophorus fasciatus $\mathrm{sp} . \mathrm{n}$. (Figs. 20-22)}

FEMALE. Coloration. Buff. Eyes black. Ocelli on bllack iubercle. Vertex with groups of small brown spots posteriorly and dorsal to eyes. Genae pale. Postclypeus with 5 or 6 narrow striae each side of midline; labrum darkened. Maxillary palpi dark brown. Antennal flagellum black. Thorax blackened dorsally; generally pale laterally, but darkened above coxae. Legs pale: apices of tibiae, whole of tarsi dark. Forewing strongly marked with dark brown as in Fig. 20. Hindwing slightly darkened near base. Abdomen with irregular dark brown markings across all terga; genitalia dark brown.

Morphology. Forewing venation as in Fig. 20; basal lengths of $R$ and $M$ with few small setae. Subgenital plate (Fig. 21) with long narrow rourided median projection bearing numerous short setae near apex; anterior sclerotised region transverse. Gonapophyses 
(Fig. 22) elongate: ventral valve siender; dorsal valve spiculate near rounded apex; external valve without lobe. Epiproct deep, membranous near apex. Paraproct elongate, with field of about 35 small trichobothria.

Dimensions. B 4.45, FW 4.31, HW 3.02, $f_{1} 0.960, f_{2} 0.990, f_{1} / f_{2} 0.970, F 0.960, T 1.920$. $t_{1} 0.570, t_{2} 0.210, t_{1} / t_{2} 2.714$, ct 28.4 .

Male. Unknown

Holotype, ㅇ, Malaise trap, 6.ix.1978

Paratype, $\circ$, same data.

\section{COMMENTS}

Few species of Metyiophorus are recorded from South America and most of these have forewings without strongly contrasted markings. The forewing of fasciatus is somewhat similar to that of 'Psocus' elegantula Banks (1920), a species known only from Bank's figure and unaccompanied by other description or note of country or origin. The wing of fasciatus is, however, considerably less heavily marked. The unusual wing pattern and greatly elongated genitalia appear to be distinctive features.

\section{Psocidus manausensis $\mathrm{sp} . \mathrm{n}$. (Figs, 23-28)}

Female. Male. Coloration. Very dark brown. Eyes black. Ocelli on black tubercle. Vertex with groups of small dark patches dorsal to eyes and along midline. Frons darkened medially. Postclypeus, anteclypeus and labrum very dark brown. Maxillary palpi and antennae brown. Thorax and legs very dark brown. Forewing marked with dark greyish brown as in Fig. 23. Hindwing browned basally and, lightly, over apical third. Abdomen with irregular dark brown dorsal markings on all terga.

Morphology. Female. Forewing venation as in Fig. 23. Subgenital plate (Fig. 27) with short blunt apical lobe. Gonapophyses (Fig. 28): ventral valve slender; dorsal valve with long apical spine; external valve transverse, with smal! apical lobe. Epiproct rounded, apical region membranous with few short setae. Paraproct with round field of about 26 trichobothria.

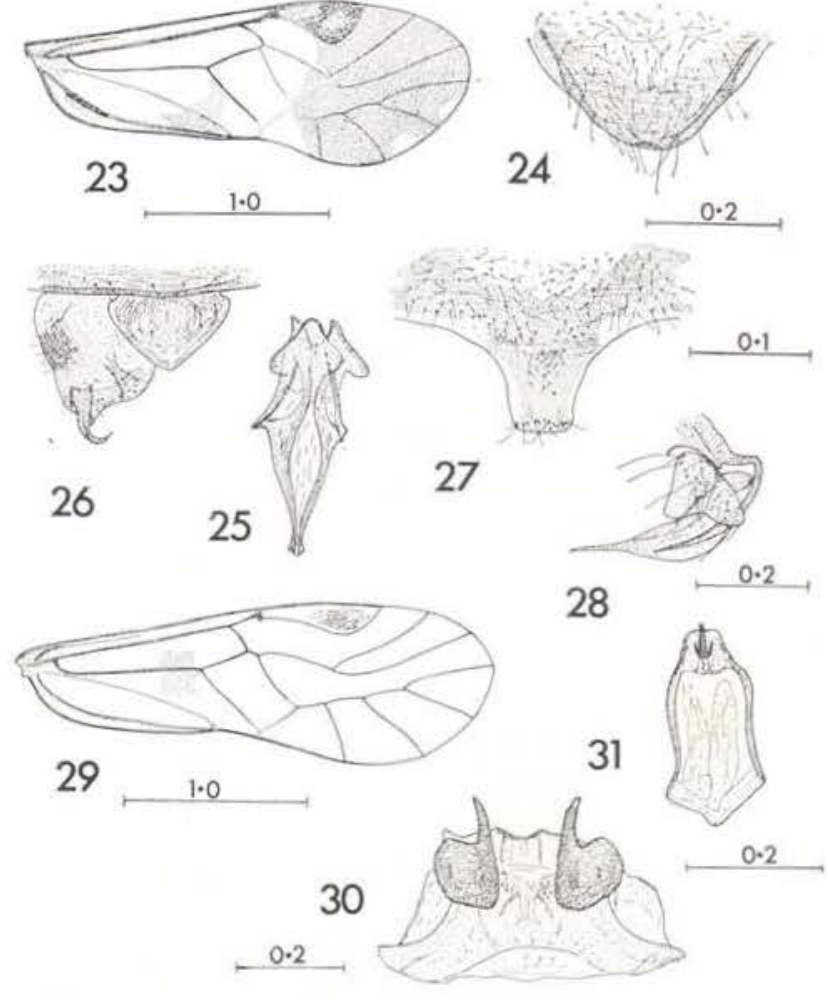

Figs, 23-31. Figs. 23-28 - Psocidus manausensis $\mathrm{sp} . \mathrm{n}$.: Fig. 23 - Forewing; Fig. 24 - Hypandrium; Fig. 25 Phallosome; Fig. 26 - Male epiproct and paraproct: Fig. 27 - Subgenital plate; Fig. 28 - Gonapophyses. Figs. 29-31 - Psocidus quadrisignatus (Banks): Fig. 29 - Forewing: Fig. 30 - Hypandrium; Fig. 31 - Phallosome. (Scales in $\mathrm{mm}$ ).

Male. Forewing as female. Hypandrium (Fig. 24) symmetrical, simple, unornamented. Phallosome frame (Fig. 25) closed: narrow anteriorly. with trilobed apex; slight lateral expansions at about half its length. Epiproct (Fig. 26) triangular, with few short setae and traces of whorled sclerotisation. Paraproct (Fig. 26) broad, with curved apical spine and field of about 18-20 small trichobothria.

Dimensions. Female, B 2.65, FW 2.60, $H W$ 1.85, $f_{1} 0.495, f_{2} 0.460, f_{1} / f_{2} 1.077, F 0.490$. $T 0.940, t_{1} 0.310, t_{2} 0.120, t_{1} / t_{2} 2.583$, ct 20.2

Male, B 2.58, FW 2.50, HW 1.77, $f_{1} 0.480$, $\mathrm{F} 0.465, T 0.930, t_{1} 0.300, t_{2} 0.120, t_{1} / t_{2} 2.500$. ct 19.2 .

Holotype, \&, Malaise trap, 2.v.1978.

Paratypes: 1 ex, 4.vii.1978; of o , 8.viii.1978; o 15.viii.1978; \&, 6.ix.1978; 2 ex, 20.ix.1978 (all Malaise trap); 1 ex, 16.v.1978, light trap. 


\section{COMMENTS}

This species is described as exemplifying a number of unusual features: in particular the form of the phallosome is unlike that of any described Psocidae. The lateral expansions resemble those of some species of Ptycta Enderlein s.I., but members of that genus typically have a hypandrium with a median tongue, and at least a trace of a spurvein from the pterostigma. Female genitalia are more similar to those of Ptycta but it appears unwise to allocate the species to any described genus at this stage. It is therefore referred to a 'holding genus', Psocidus Pearman, and the wing markings apparently differ from ail other $\mathrm{S}$. American taxa included in that genus, although a number of these have not been described in detail.

\section{Psocidus quadrisignatus (Banks)}

Psocus quadrisignatus Banks, 1920: 305

Psocidus quadrisignatus (Banks). Smithers, 1967: 110. (Figs. 29-31)

MALE. Coloration. Essentially as in original description: postclypeus with traces of 5 or 6 narrow striae each side of midline; anteclypeus and labrum darkened; forewing markings as in Fig. 24.

Morphology. Forewing venation as in Fig. 29. Hypandrium (Fig. 30) symmetrical, with 2 broad, heavily-sclerotised rugose posterodorsal hooks; central border slightly rugose. Phallosome frame (Fig. 31) closed, elongate; a broad truncate apex with narrow spike inserted before apex; slight anterolateral lobes. Epiproct rounded, with bluntly-rounded dorsal flap extending about half its length. Paraproct with apical spine and a field of about 30 trichobothria.

Dimensions. B 2.90, FW 2.73, HW 1.96. $\mathrm{F} 0.585$. T 1.140, $\mathrm{t}_{1} 0.390, \mathrm{t}_{2} 0.120, \mathrm{t}_{1} / \mathrm{t}_{2} 3.250$. ct 21.3 .

Material examined, 1 s, light trap, 6. xii. 1977.

\section{COMMENTS}

P. quadrisignatus, the type of which has not been reexamined, was described from 'Brazil', and Banks' figure of the forewing tallies closely with that of the present species: the markings appear to be distinctive. Banks also notes the large tarsal ratio of the nindleg but his specimen appears to be somewhat larger than the present one.

The unusual ornamentation of the hypandrium, and the preapical phallosome spine do not correspond with features of any known genus, and the species is therefore retained in Psocidus s.1.

\section{MYOPSOCIDAE}

Myopsocus ariasi sp. $\mathrm{n}$. (Figs. 32-35)

FEMALE, Unknown.

MALE. Pale brown, Eyes black. Ocelli on black tubercle. Central region of frons and vertex darkened; anteclypeus and labrum dark brown. Apical segment of maxillary palpi very dark. Thorax darkened dorsally, paler laterally. Legs with apex of tibiae and much of tarsi dark brown. Forewing (Fig. 32) heavily marked with greyish brown. Hindwing hyaline. Abdomen pale irregularly darkened dorsaliy.

Marphoiogy. Forewing venation as in Fig 32. Hindwing $R_{S}$ and $M$ linked by crossvein. Hypandrium (Fig. 33) broad, rounded; unornamented, although parts of border thickened. Phallosome (Fig. 34) slightly broadened posteriorly, frame only membranously closed pos. teriorly; a strong longitudinal median bar. broadened and incipiently bifurcate posteriorly. Epiproct (Fig. 35) broad, with a broad shallow dcrsal flap near base. Paraproct (Fig. 35) with a straight unornamented inner process and a broader blunt outer process bearing short setae; a field of about 32 small trichobothria and 2 or 3 central setae without basal rosettes.

Dimensions. B 3.15, FW 2.97, HW 2.20. F $0.540 \mathrm{~T} 1.050, \mathrm{t}_{1} 0.375, \mathrm{t}_{2} 0.050, \mathrm{t}_{3} 0.090$, $\mathrm{t}_{1} / \mathrm{t}_{2} 7.500, \mathrm{t}_{2} / \mathrm{t}_{3} 0.556$, ct 19.1 .1 .

Holotype, so, light trap 6.xii.1977.

\section{COMMENTS}

This species is rather similar to $M$. pulchellus New and Thornton (1975, Brazil) but differs in details of body and leg coloration and in having more regular wing pattern which is overall darker than in pulchellus. Males of pulchellus are unknown. 
Phlotodes pennyi sp. $\mathrm{n}$.

(Figs. 36-39)

FEMALE. Unknown.

MALE. Coloration. Dark brown. Eyes black. Ocelli in small black annuli. Small discrete brown spots dorsal to eyes and across posterior of vertex; central region of frons darkened. Postclypeus with striae towards mid́line; anteclypeus pale; labrum dark brown Maxiliary palpi dark brown. Thorax darkened dorsally on lobes. Legs dark brown except for base of $t_{1}$ and short preapical lengths of tibiae. Forewing marked with greyish brown as in Fig. 36. Hindwing hyaline. Abdomen greyish brown, with darker dorsal mottling.

Morphology. Forewing venation as in Fig. 36. Hindwing with $R_{S}$ and $M$ fused for a length. Hypandrium (Fig. 37) rounded, with small bifurcate median apical process. Phailosome

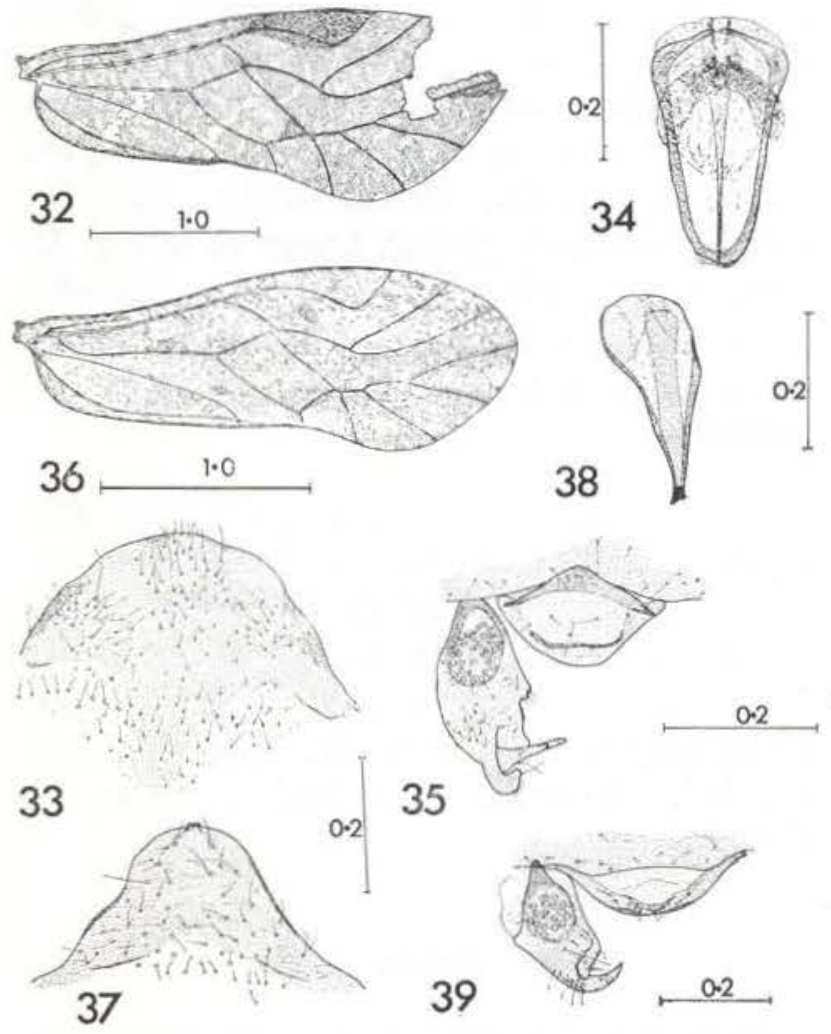

Figs. 32-39. Figs. $32-35-$ Myopsocus ariasi sp. n.: Fig. 32 - Forewing; Fig. 33 - Hypandrium; Fig. 34 - Phal. losome; Fig. 35 - Male epiproct and paraproct. Figs. 36-39 - Phlotodes pennyi sp. n.: Fig. 36 - Forewing; Fig. 37 - Hypandrium; Fig. 38 - Phallosome; Fig. 39 Male epiproct and paraproct. (Scales in $\mathrm{mm}$ ).
(Fig 38), elongate, strongly tapered and with broad median tongue. Epiproct (Fig. 39) shallow and very broad, with small setae near apex. Paraproct (Fig. 39) with tapered curved apical spine; a field of 17 trichobothria, and 2 central setae without basal rosettes.

Dimensions. B 3.00, FW 2.40, HW 1.87, F $0.450, T 0.880, t_{1} 0.315, t_{2} 0.045, t_{3} 0.060$, $\mathrm{t}_{1} / \mathrm{t}_{2} 7.000, \mathrm{t}_{2} / \mathrm{t}_{3} 0.750$, ct 18.1 .1 .

Holotype, s, ligth trap, 8.xi.1977.

Paratypes, 2 ô $\hat{o}$, light trap 6 and 29.xii.1977.

COMMENTS

Of the South American Myopsocidae, only P. minor New \& Thornton (1975, Brazil) is of similar size to the present species, and is the only Neotropical species confirmed as belonging to Phlotodes. P. pennyi differs considerably from minor in wing and genitalic features.

\section{Lophopterygella albomaculata sp. n. (Figs. 40-42)}

FEMALE, Coloration. Pale brown Eyes black. Ocelli on small black tubercle. Several small dark brown spots dorsal to each eye and on posterior half of vertex. Central region of frons and postclypeus darkened; anteclypeus and labrum dark brown. Maxillary palpi black. Antennae base dark brown. Thorax darkened dorsally. Legs with coxae very dark brown, femora with 2 pale bands near apex, apex of tibiae and whole of tarsi darkened. Forewing (Fig. 40) strongly marked with greyish brown; cells $M_{1}$ and $M_{2}$ with conpicuous white marginal spots. Hindwing hyaline except for slight darkening of apical border. Abdomen dark brown, irregularly shaded dorsally.

Morphology. Forewing (Fig. 40) with margin sinuous between branches of $M$; pterostigma sharply angled; e pronounced flap on vein $1 \mathrm{~A}$. Hindwing with $\mathrm{R}_{S}$ and $M$ fused for a short length. Subgenital plate (Fig. 41) with slender apical process bearing 2 setae; posterior sclerotised region almost completely separated from larger anterior sclerotised 
region. Gonapophyses (Fig. 42): ventral valve very short. Epiproct broad, rounded. Paraproct broad, with a field of about 24 trichobothria.

Dimensions. B 3.70, FW 3.35, HW 2.63, $F 0.705, T 1.320, t_{1} 0.435, t_{2} 0.060, t_{3} 0.090$, $\mathrm{t}_{1} / \mathrm{t}_{2} 7.250, \mathrm{t}_{2} / \mathrm{t}_{3} 0.667$, ct 16.1 .1 .

Male. Unknown.

Holotype, 9 , light trap, 6.xii.1977.

Paratype, + , same data.

\section{COMMENTS}

Lophopterygella has not previously been recorded from the mainland of South America, although one species was described from Haiti (Banks 1938). The present species, and the next, both differ from Lophopterygella sensu stricto in having $R_{S}$ and $M$ in the hindwing fused for a length, rather than linked

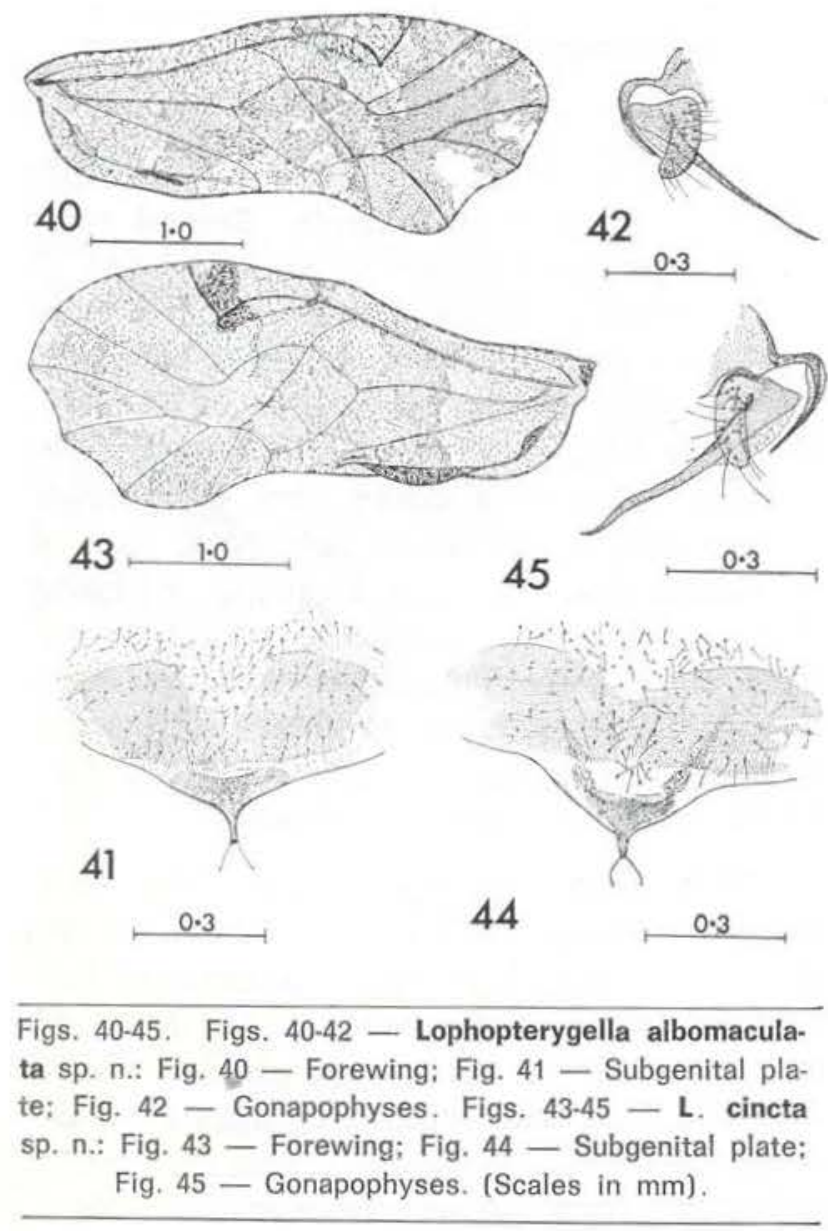

by a crossvein, and are thus perhaps aberrant species of Myopsocus Hagen. However, the pronounced incurring of the forewing margin between branches of $M$ is regarded as the most distinctive feature of Lophopterygella and the species are thus referred to this genus.

The two species described here differ substantially from each other, and from haitiensis Banks (1938) on features of forewing pigmentation. The two Brazilian species are further separable on features of the subgenital piate: genitalia of haitiensis are unknown.

\section{Lophopterygella cincta sp. n. (Figs. 43-45)}

FEmale. Cobration. Pale greyish brown. Eyes black. Ocelii on small black tubercle. Central region of vertex and frons darkened. Postclypeus with traces of striae anteriorly; anteclypeus and labrum dark brown. Apical segment of maxillary palp very dark brown. Thorax slightly darkened dorsally. Legs mainly very dark brown; apex of femora, of tibiae, and whole of $t_{1}$ pale, almost white. Forewing mottled with pale greyish brown as in Fig. 43; apex of pterostigma castaneous. Hindwing hyaline, except for slight darkening of apical border. Abdomen with irregular greyish dorsal mottling.

Morphology. Forewing venation (Fig. 43); a prominent flap on vein $1 \mathrm{~A}$. Subgenital plate (Fig. 44) with tapered narrow median lobe bearing 2 setae; posterior sclerotised region linked laterally with anterior sclerotisation. Gonapophyses as in Fig. 45. Epiproct broad, rounded. Paraproct with field of about 26 trichobothria.

\section{Resumo}

Novas espécies de Musapsocus (1), Thyrsopsocus (1), Psococerastis (1), Metylophorus (1), Psodicus (1), Myo. psocus (1), Phlotodes (1), e Lophopterygella (2) provenientes do Brasil, săo descritas e ilustradas. Descrições adicionais sâo dadas para Cervopsocus medialis New e Psocidus quadrisignatus (Banks). Musapsocus e Lophopterygella são citadas para o Brasil pela primeira vez. 


\section{REFERENCES}

BANKS, N

1920 - New Neuropteroid Insects. Bull. Mus comp. Zool., Harvard., 64: 299-362.

1928 - New West Indian Neuropteroid Insects. Revta. Ent., Rio de J., 9: 285-304.

ENDERLEIN, G.

1900 - Die Psociden fauna Perus. Zool. Jb. Abt. Syst., 14: 133-160.

MOCKFORD, E.L.

1967 - The Electrentomoid Psocids (Psocoptera). Psyche, Camb., Mass., 74: 118-165.

NEW, T.R.

1978a- An appraisal of the Thyrsophorinae stat. nov. (Psocoptera, Psocidae) and of its cons. tituent genera from the Neotropics. Syste. matic Entomology, 3: 35-49. 1978b- Notes on the complex of species allied to Psococerastis taprobanes (Hagen) (Psocoptera, Psocidae). Ent Brasil 3: 235-248.

$1978 \mathrm{c}$ - Notes on some unusual Psocidae (Psocoptera) from Brazil. Revta. Bras. Ent., 22: 11-18.

sd - Epipscocetae (Psocoptera) from the Reserva Ducke, Amazonas. Acta Amazonica,

NeW, T.R. \& THORNTON, I.W.B.

1975 - Psocomorpha (Psocoptera) collected on recent expeditions to South America. J. Ent., (B) 44: 27-80.

SMTTHERS, C.N

1967 - A Catalogue of the Psocoptera of the World. Aust. Zool., XIV. 1-145.

(Aceito para publicação em 27/07/79). 